\title{
Cardiac Natriuretic Peptides, Hypertension and Cardiovascular Risk
}

\author{
Riccardo Sarzani $^{1,2}$ (10) Francesco Spannella $^{1,2} \cdot$ Federico Giulietti $^{1,2}$ • \\ Paolo Balietti ${ }^{1,2} \cdot$ Guido Cocci $^{1,2} \cdot$ Marica Bordicchia $^{1}$
}

Received: 20 February 2017 / Accepted: 27 March 2017/Published online: 4 April 2017

(C) The Author(s) 2017. This article is an open access publication

\begin{abstract}
Prevalence of cardiovascular (CV) disease is increasing worldwide. One of the most important risk factors for $\mathrm{CV}$ disease is hypertension that is very often related to obesity and metabolic syndrome. The search for key mechanisms, linking high blood pressure (BP), glucose and lipid dysmetabolism together with higher CV risk and mortality, is attracting increasing attention. Cardiac natriuretic peptides (NPs), including ANP and BNP, may play a crucial role in maintaining $\mathrm{CV}$ homeostasis and cardiac health, given their impact not only on BP regulation, but also on glucose and lipid metabolism. The summa of all metabolic activities of cardiac NPs, together with their CV and sodium balance effects, may be very important in decreasing the overall $\mathrm{CV}$ risk. Therefore, in the next future, cardiac NPs system, with its two receptors and a neutralizing enzyme, might represent one of the main targets to treat these multiple related conditions and to reduce hypertension and metabolic-related CV risk.
\end{abstract}

Keywords Cardiac natriuretic peptides - Hypertension · Cardiovascular risk $\cdot$ Obesity $\cdot$ Metabolism

Riccardo Sarzani

r.sarzani@univpm.it

1 Internal Medicine and Geriatrics, Department of Clinical and Molecular Sciences, University "Politecnica delle Marche", Ancona, Italy

2 Italian National Research Centre on Aging, Hospital "U. Sestilli", IRCCS-INRCA, via della Montagnola n. 81, 60127 Ancona, Italy

\section{Introduction}

The prevalence of cardiovascular disease (CVD) is increasing worldwide. One of the most important risk factors for CVD is hypertension, which affects more than one billion people throughout the world. The global prevalence of hypertension is projected to increase up to 1.5 billion by 2025 [1]. A recent Italian survey reveals that, in the setting of general practice, the prevalence of diagnosed hypertension raised from $19.3 \%$ over 615,373 individuals reported in 2005 to $25.9 \%$ over 911,754 individuals reported in 2013 [2]. Moreover, worldwide prevalence of obesity has nearly doubled in the past few decades and it is estimated that 592 million people will be living with diabetes mellitus by 2035 [3, 4]. Overweight and obesity are tightly associated with elevated BP and about $75 \%$ of essential hypertension cases have been estimated to be overweight/obesity-dependent [5].

The search for key factors, linking excessive adiposity and glucose/lipid dysmetabolism with higher BP and CV risk, is attracting increasing attention. A possible integrated vision may lie in the central role of cardiac natriuretic peptides (NPs) and their system composed by two receptors, mediating opposite effects, and a neutralizing enzyme. It is a fundamental endocrine, autocrine and paracrine system which maintains CV homeostasis and health [6]. These molecules have important roles not only in the regulation of BP, blood volume and sodium balance, but also in glucose and lipid metabolisms in adipose and muscle tissues [7].

Our narrative review focuses on this topic, analyzing the associations between cardiac NPs, hypertension and metabolic-related $\mathrm{CV}$ risk. 


\section{Pathophysiology of Cardiac Natriuretic Peptides}

The cardiac endocrine function was identified in the second half of the twentieth century. In 1984, Kangawa et al. described the structure of atrial natriuretic peptide (ANP) [8]. In 1988, brain natriuretic peptide (BNP) was isolated from porcine brain and then was found to be synthesized and secreted by ventricular myocardium [9]. In 1990 a third NP was isolated also from pig brain and called C-type natriuretic peptide (CNP) [10].

In the following review, we will report and discuss mostly of ANP and BNP, collectively called "cardiac NPs", because they are real hormones produced by the heart with the ability to affect distant target tissues and organs [11] (Fig. 1).

Cardiac NPs are synthesized as precursor proteins and undergo intracellular modification to prohormones. ProANP is stored in atrial granules and cleaved into the 98 aminoacid N-terminal fragment (NT-proANP) and the 28 aminoacid active hormone (ANP), on release into the circulation. Pro-BNP is synthesized and secreted in bursts, released from ventricular myocytes as a 76 aminoacid $\mathrm{N}$-terminal fragment (NT-proBNP) and a 32 aminoacid active hormone (BNP) very similar to ANP. Gene expression of BNP can increase very rapidly in response to an appropriate stimulus, unlike ANP gene expression [12].

Primary stimulus for the release of cardiac NPs is muscular wall stretch, resulting from increased intravascular volume and/or cardiac transmural pressure, in conditions of cardiac stress, such as heart failure (HF), even with preserved ejection fraction, myocardial infarction or cardiomyopathies [13, 14]. Although ANP concentrations are more closely related to left-atrial pressure and BNP to left-ventricular pressure and volume indices [15], some overlap between sites of release exists. For instance, BNP is released in small amounts also from atrial tissue [16], and ANP can be released from both atrial and ventricular tissues in large quantities, in patients with myocardial infarction or left ventricular dysfunction [17].

In physiological conditions, cardiac and plasma BNP levels are much lower than ANP levels. In fact, ANP seems to have a more physiological action, influencing and controlling normal cardio-renal activities, while BNP seems to be produced mainly in response to a cardiac stress or pathological challenges [18].

Three subtypes of NP receptors have been identified: NP receptor A (NPRA), B (NPRB) and C (NPRC). NPRA and NPRB are guanylyl cyclase (GC) coupled transmembrane receptors. The binding to the NPRA and NPRB induces the generation of the second messenger cyclic guanosine monophosphate (cGMP), which mediates most of the NPs biological effects $[19,20]$. ANP and BNP bind selectively to NPRA, while CNP binds to NPRB. NPRC does not have GC activity, and it is mainly a clearance receptor for NPs, because it facilitates their internalization and degradation [21]. NPs are also inactivated by a neutral endopeptidase called neprilysin, that is present on the surface of endothelial cells, smooth-muscle cells, cardiac myocytes, renal epithelium and fibroblasts [22]. NPRC, assisted by neprilysin, is the most important negative modulator of circulating NPs levels and the main silencer of their biological effects at cellular level [7]. Cellular and systemic effects of NPs depend on receptors distribution, ligandaffinity and NPRA to NPRC expression ratio (NPRA/ NPRC) [21, 23]. NPRA is expressed mainly in vascular smooth muscle and endothelial cells, adipose tissue and

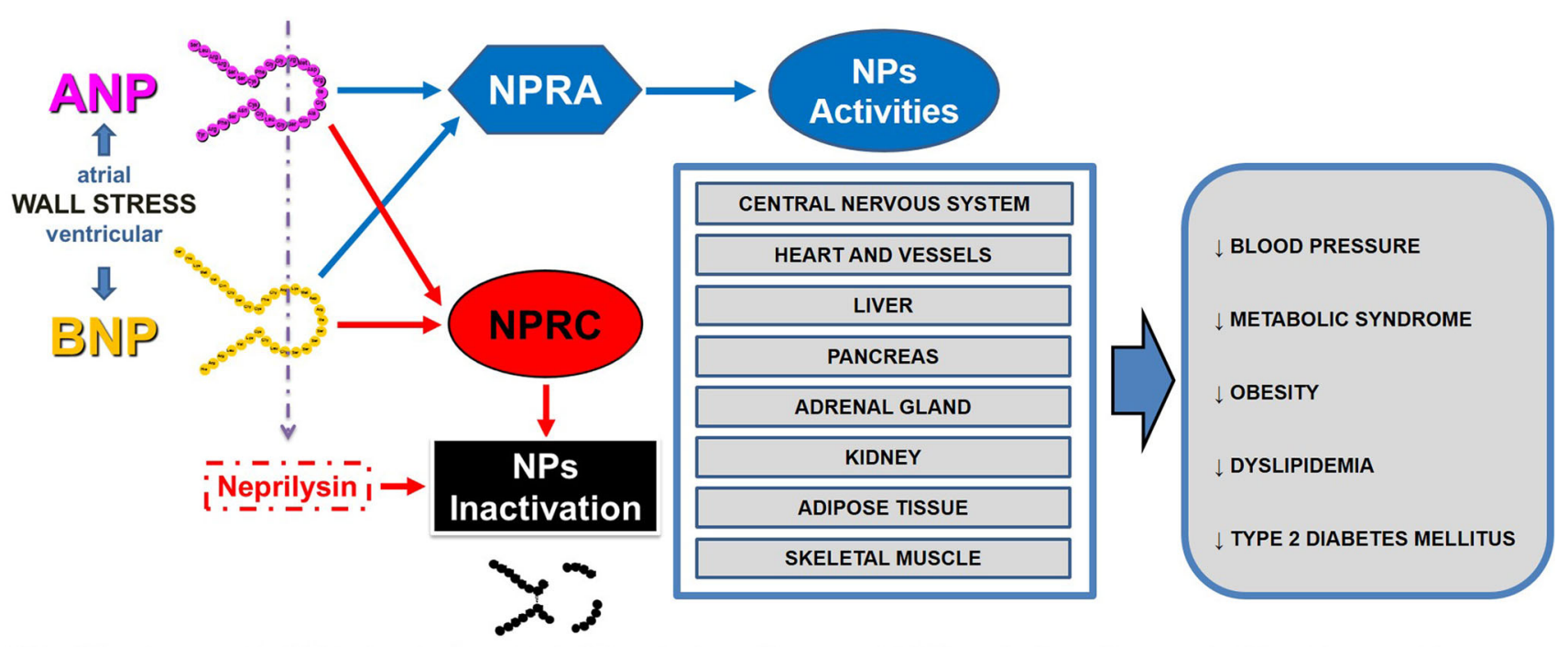

ANP: atrial natriuretic peptide; BNP: brain natriuretic peptide; NPRA: natriuretic peptide receptor A; NPRC: natriuretic peptide receptor C; NPs: natriuretic peptides.

Fig. 1 Pathophysiology and clinical implications of cardiac natriuretic peptides system 
kidneys, adrenal gland, liver and brain and to a lesser extent in the heart and skeletal muscle [21]. NPRC is mainly expressed in adipose tissue and kidney and it is involved in degradation of all types of NPs, with highest affinity for ANP and lowest affinity for BNP [24]. The lower affinity of NPRC for BNP is a major contributor of the longer plasma half-life of BNP, compared to ANP, in humans [25]. It follows that the reported half-life of ANP is approximately $2 \mathrm{~min}$ in normal human subjects [26], while the removal of BNP from human circulation recognizes short and long half-life components of 3.9 and $20.7 \mathrm{~min}$, respectively [25]. Regarding the comparison between BNP and NT-proBNP, two of the most useful biomarkers in clinical practice, the fact that the former has a half-life approximately six times shorter than the latter, led to hypothesize a way to convert BNP to NT-proBNP levels and vice versa, even though this has not yet been clinically verified [27].

Cardiac NPs circulating levels may be affected also by gender. In fact, estradiol was found to enhance NPRA expression levels while stabilizing or reducing NPRC transcription levels in mice. Sex-dependent NPs regulation could contribute to the well-known gender differences in fat distribution and CV risk between women and men [24].

ANP and BNP exhibit similar actions in all cell types studied, as shown in Table 1. Unlike ANP and BNP, CNP is expressed mostly in central nervous system and vascular and peripheral tissues, rather than in the heart [28]. It does not act as an endocrine hormone, but as a paracrine/autocrine factor in the vasculature, mainly as a vasodilator and inhibitor of vascular cell proliferation and also as a lipolytic factor in adipocytes as well as ANP and BNP [29]. A different processing of pro-peptide from ANP gene leads to an ANP-variant called urodilatin, synthesized in renal tubule cells and isolated from urine, with a possible role in sodium and water homeostasis in kidney [30].

During the last decade, NPs have been shown to exert also a variety of metabolic effects, as briefly reviewed below.

\section{Cardiovascular and Metabolic Effects of Cardiac Natriuretic Peptides}

\subsection{Cardiac NPs and Renin Angiotensin Aldosterone System}

Hypertension, excessive adiposity, especially intra-abdominal, and metabolic syndrome (MetS) are often coexisting conditions. The increased visceral adiposity is strongly associated with deranged metabolism of glucose and lipids, and increased BP [7, 31]. Two main antagonistic circulating regulatory systems may be associated with these conditions: cardiac NPs and renin angiotensin

Table 1 Principal roles of NPs in CV homeostasis and metabolism

\begin{tabular}{|c|c|c|}
\hline & ANP & BNP \\
\hline Metabolic effects & $\begin{array}{l}\text { - Increased lipolysis through HSL, Perilipin, ATGL } \\
\text { - Increased browning of white adipocytes via UCP1, } \\
\text { PGC1alpha } \\
\text { - Decreased inflammatory cytokines and increased } \\
\text { adiponectin } \\
\text { - Type } 2 \text { Diabetes/Insulin resistance } \\
\text { - Induced mitochondrial biogenesis (CYTO C) }\end{array}$ & $\begin{array}{l}\text { - Increased lipolysis through HSL, Perilipin, ATGL } \\
\text { - Increased browning of white adipocytes via UCP1, PGC1alpha, } \\
\text { irisin } \\
\text { - Decreased inflammatory cytokines and increased adiponectin } \\
\text { - Type } 2 \text { Diabetes/Insulin resistance } \\
\text { - Induced adipocytes and muscle mitochondrial biogenesis (CYTO } \\
\text { C) and lipid oxidation rate } \\
\text { - Appetite/satiety (ghrelin) }\end{array}$ \\
\hline $\begin{array}{l}\text { Cardiovascular } \\
\text { effects }\end{array}$ & $\begin{array}{l}\text { - Increased renal perfusion, GFR and natriuresis } \\
\text { - Arterial and venous dilation } \\
\text { - RAAS inhibition } \\
\text { - SNS inhibition } \\
\text { - Vasopressin inhibition } \\
\text { - Myocardial relaxation } \\
\text { - Cardiac anti-fibrotic and anti-hypertrophic effects } \\
\text { - Increased vascular permeability } \\
\text { - Vascular anti-fibrotic and anti-hypertrophic effects } \\
\text { - Anti-atherosclerotic properties }\end{array}$ & $\begin{array}{l}\text { - Increased renal perfusion, GFR and natriuresis } \\
\text { - Arterial and venous dilation } \\
\text { - RAAS inhibition } \\
\text { - SNS inhibition } \\
\text { - Vasopressin inhibition } \\
\text { - Myocardial relaxation } \\
\text { - Cardiac anti-fibrotic and anti-hypertrophic effects }\end{array}$ \\
\hline
\end{tabular}


aldosterone system (RAAS). The head-to-head between NPs and RAAS appears of key value to understand the pathophysiology of obesity-related complications such as hypertension, insulin resistance and MetS [7, 32].

All RAAS components are increased in visceral adiposity [33, 34]. The abnormal RAAS regulation in obesity appears to be the result of an increased RAAS activity and a defective NPs activity. Indeed, NPs beneficial effects on CV system partially depend on their ability to antagonize RAAS at multiple levels [35].

The sympathetic nervous system (SNS) is another overactivated system in obese patients, even when normotensives, and it is related to multiple pathophysiological processes including increasing BP, maybe as an attempt to increase energy expenditure through beta-receptor activation [36]. It is at least conceivable that a reduced NPs activity may be the 'primum movens' of the increased/ unsuppressed activity of RAAS and SNS.

\subsection{Cardiac NPs, Lipolysis and Thermogenesis}

The relationship between NPs system and adipose tissue is very strong. Among human tissues, adipose tissue is the second largest expression site of NPRC after kidney. NPRA is also abundantly expressed in adipose tissue and the NPRA/NPRC expression ratio regulates the final biological NPs effects [21].

In adipose tissue, both NPs system and RAAS affect cellular growth and metabolism. Angiotensinogen and angiotensin II, at least in some conditions, stimulate visceral adipocyte growth, differentiation through AT1-receptors and inhibition of lipolysis in adipocytes of normalweight and obese subjects [37]. On the other side, NPs inhibits adipocyte proliferation, through NPRA [38] and stimulate also lipolysis leading to increased non esterified fatty acids (NEFA) circulating levels [24]. The lipolytic properties of NPs were first described by Sengenès et al., who observed that ANP was the most potent activator of lipolysis, followed by BNP and CNP [39]. Among others, the importance of NPs role in lipolysis was shown also by Bordicchia et al., who demonstrated that NPRC $-/-$ mice are lean, possess smaller adipocytes and contain significantly increased amounts of lipolysis, UCP1 and other features of brown adipocytes [40]. Protein kinase G activation by NPs promotes perilipin $\mathrm{A}$ and degradation of triglycerides mediated by hormone sensitive lipase. Thus, NPs induce higher free fatty acid availability as substrate for oxidation in tissues such as skeletal muscle, liver and brown adipose tissue, and at the same time enhance this process, by inducing mitochondrial biogenesis, oxygen consumption and thermogenesis [40, 41]. In fact, higher levels of circulating NEFA, produced by NP-mediated lipolysis, are carried by adipose fatty acid binding protein
(FABP) to brown adipose tissue in order to increase energy dissipation through heat production [42].

Another complex interaction exists between NPs and insulin, suggesting that NPs strongly affect not only lipid metabolism but also glucose metabolism. Insulin attenuates NPs-mediated lipolysis indirectly by reducing circulating NPs levels and enhancing NPRC expression in white adipose tissue in rodents and humans [43, 44]. A recent study have confirmed that high insulin levels, together with high glucose concentration (as in impaired glucose tolerance of MetS), induced NPRC overexpression in human adipocytes, blocking NP-mediated lipolysis and thermogenic pathway, and potentially contributing to lower energy dissipation, increase adiposity, insulin resistance and BP. In contrast, when insulin was not coupled with high glucose concentration, simulating fasting condition and suggesting a "nutritional signaling", NPRC gene expression was not induced [32]. It is possible to speculate that the strong lipolytic effects of NPs are counterbalanced by insulin and insulin-mediated NPRC induction.

Calorie intake represents another important regulator of NPs receptors expression in adipocytes. Fasting is associated with a robust downregulation of NPRC expression in adipose tissue, while NPRA expression is not reduced or may even increase [45]. The increased NPs activity, due to the diffuse NPRC downregulation in adipose tissue, may have a role in the "natriuresis of fasting" and in the decreased BP in fasting and very-low calorie diet. In obese hypertensive patients, the effect of ANP infusion on lipolysis was significantly emphasized after a very-lowcalorie diet [46]. Recent evidences showed an influence on dietary behavior and food intake by NPs. In human subjects, short-term BNP infusion suppressed hunger, maybe through the reduction of total and acetylated ghrelin concentrations [47].

BNP is also positively correlated with adiponectin, an adipocyte-specific anti-inflammatory anti-atherosclerosis adipokine, involved in the chronic low-grade inflammation of MetS. In fact, NP infusion raises adiponectin plasma levels via NPRA in healthy adults and in patients with HF [48]. Moreover, ANP inhibits the release of pro-inflammatory cytokines and chemokines from human adipocytes and adipose tissue macrophages [24]. The mechanism could be beneficial because chronic, low-grade inflammation might contribute to obesity-associated insulin resistance and CVD.

\subsection{Cardiac NPs and Energy Expenditure}

NPs receptors are expressed also in skeletal muscle, where NPs increase oxidative capacity [24]. In experimental models, they promote mitochondrial biogenesis and fatty acid oxidation with a protective action against skeletal 
muscle atrophy [41]. Some authors support the idea that these favorable metabolic properties may help against the age-related changes in adipose tissue (increase in visceral fat with "whitening" of adipose tissue) [49] as well as in skeletal muscle mass and quality, opposing sarcopenia [50]. This large range of effects on adipose and skeletal muscle tissues suggests a possible role of NPs in mediating the health beneficial effects observed in response to exercise. In humans, plasma ANP and BNP levels increase after exercise [51], together with higher expression of NPRA and decreased NPRC function in skeletal muscle [24]. In obesity and MetS, NPs may improve lipid-induced insulin resistance, associated with hepatic and skeletal muscle lipid content, through increased mitochondriogenesis, stimulation of mitochondrial "respiration" and also uncoupling mitochondrial respiration and enhancing lipid oxidation in adipose tissue [24]. In fact, in mice models by Miyashita et al., chronic overexpression of BNP led to increased muscle mitochondrial content, oxidative capacity, lipid oxidation and resistance to diet-induced obesity. On the contrary, NPRA knockout was associated with increased susceptibility to obesity and insulin resistance [41]. Therefore, NPs are likely to combine the increased lipolysis/increased NEFA levels with a more efficient energetic metabolism in muscles through NEFA burning, resulting in improved cardiac and muscle metabolism with fewer metabolic complications [7].

We believe that the summa of all these metabolic activities of cardiac NPs, together with their CV and sodium balance effects, may be very important in decreasing the overall $\mathrm{CV}$ risk.

\section{Clinical Implications of Cardiac Natriuretic Peptides}

\subsection{Cardiac NPs, Metabolic Syndrome and Type 2 Diabetes Mellitus}

All the interactions between NPs, glucose and lipid metabolisms involving both adipose and skeletal muscle may have a relevant impact on the association between NPs and several CV risk factors. In clinical studies, higher NPs levels were associated with less obesity and MetS [52] and a decreased risk of incident type 2 diabetes (DM2) [53, 54]. Studies of genetic variants in NPs precursor A (NPPA) and $\mathrm{B}$ (NPPB) suggest that mild elevations in NPs, also in physiological range, may protect against DM2 [54, 55]. This relationship has been observed principally in middleaged cohorts, but it may be relevant also in the pathophysiology of DM2 in elderly, where important age-related changes, such as decline in skeletal muscle mass and quality, result in an increased peripheral insulin resistance (as discussed above) $[50,56]$. The mechanisms behind the association between NPs and DM2 risk are not completely understood, but the central role of these cardiac hormones on metabolism and energy expenditure may explain, at least in part, the development of obesity and glucose dysmetabolism, leading to age-related insulin resistance and dysglycemia [57]. The increased calorie intake, commonly found in patients with MetS and DM2, is associated with multiple consequences of the increased insulin secretion and glucose entry in adipocytes, such as the inhibition of NPs effects on adipose tissue (lipolysis, heat production and "browning" of white adipocytes). Numerous studies demonstrated an inverse relationship between circulating cardiac NPs levels and increased NPRC expression and bodyweight $[58,59]$. Increased NPs levels, due to NPRC $\mathrm{C}(-55) \mathrm{A}$ polymorphism, were found to be associated with lower prevalence of overweight, obesity, and abdominal adiposity [60]. It is unclear why, even in the context of documented cardiac overload and increased NPs release from the heart, NT-proANP and NT-proBNP tend also to be reduced in obesity, leading us to speculate that the adipose tissue can be a site of clearance of NT-peptides through a NPRC-independent mechanism.

\subsection{Cardiac NPs and Hypertension}

Cardiac NPs system appears to be a key candidate among potential factors involved in the pathogenesis of hypertension. Genome-wide association studies have found that the genes for BNP and NPRC are among the most relevant ones in essential hypertension, whereas none of the RAAS genes was identified as a contributor to the polygenicity of essential hypertension [61]. Some evidences suggest that hypertension might be the result of a deficiency in biologically active NPs. Studies in genetically-modified animal models suggest a protective effect of NPs on cardiac and renal structure as well as function and survival [62] Studies with genetic variants of NPs genes, resulting in higher plasmatic NPs concentrations, have reported lower $\mathrm{BP}$ and a reduced susceptibility to hypertension. Among others, the minor allele at rs5068 NPPA variant, associated to higher ANP levels, plays a fundamental protective role in hypertension risk, with a $15 \%$ reduction in odds of hypertension [63, 64]. Moreover, the same allele is also associated with lower BMI, lower prevalence of obesity, lower waist circumference and higher HDL cholesterol levels $[59,65]$. These findings support the existence of a genetic predisposition to hypertension that is characterized by lower circulating levels and/or activities of cardiac NPs as well as tightly associated with metabolic traits. Cardiac NPs lower BP values through several mechanisms, as shown in Table 1. All these mechanisms are also involved in the development of resistant hypertension and NPs could 
become a promising therapy in the treatment of resistant hypertension in near future [30]. A lack of biologicallyactive cardiac hormones has been reported in hypertensives, suggesting a relative deficiency of their endogenous cardiorenal protective actions in this morbid condition, although BNP levels were found to increase at increasing stages of hypertension, probably in response to greater cardiac stress [66]. Indeed, Macheret et al. found that, in a general population of 2082 adults, reduced levels of mature BNP1-32 in early stages of hypertension were accompanied by a lack of activation of its precursor, proBNP1-108. Moreover, they found that most NPs forms tend to decrease or are significantly decreased in early hypertension and then tend to increase only in late hypertension. These findings confirm the existence of a relative deficiency of such protective hormonal system, possibly due to an impaired release and/or to an elevated metabolism of the mature and biologically active forms of these cardiac hormones [67]. In any case, dual inhibition of angiotensin II receptor and neprilysin, by increasing circulating NPs levels, led to a greater BP reduction, compared to angiotensin II receptor blockade alone [68].

It is important to remember that there is a continuous resetting between the highly variable cardiac secretion of ANP and BNP and their peripheral clearance, making extremely difficult to extrapolate all this from steady-state levels of circulating NPs. In a mouse model lacking NPRC gene, circulating ANP levels were not increased but their half-life and biological effects were significantly increased, indicating a resetting of cardiac secretion (reduction) in the context of increased biological activities of NPs [69].

Cardiac NPs system appears also to have a role in protecting the heart against hypertrophy [70-72]. Rubattu et al. showed that an ANP gene promoter variant, responsible for a significant down-regulation of ANP gene transcription, together with NPRA gene molecular variants, responsible for a reduced NPRA activity, were associated with $\mathrm{LVH}$ in essential hypertension, independently from BP levels, anthropometric and clinical factors [70]. ANP circulating levels and activity also depend on corin levels, the pro-ANP activating enzyme in the heart. Moreover, recently it was found that corin activation is mediated by proprotein convertase subtilisin/kexin 6 (PCSK6), a protease of the PCSK family. The contribution of PCSK6 to the development of human hypertension and its sequelae is still unclear, but it may become a reasonable target to modulate ANP levels [73].

On the other hand, cohort studies have proved that plasma ANP levels are increased in essential hypertensives with LVH [74]. However, these elevated ANP levels in pathological conditions may represent a protective and compensatory response to cardiac wall stress. Another pathological condition associated with increased NPs levels is renovascular hypertension. In fact, the well-known increase in plasma renin activity, which causes the increase in BP, is also accompanied by high plasma levels of ANP, that may attenuate the up-regulation of renin synthesis and release, and may thereby buffer renin-dependent hypertension [75].

In short, it seems that higher cardiac NPs levels in physiological conditions may be protective against CVD, acting also against obesity and glucose/lipid dysmetabolism, while high/very high levels in pathological conditions may represent the impact of such conditions on the CV system, which attempts to counteract them by releasing its own cardiac hormones.

\subsection{Cardiac NPs in CV Risk Assessment}

Heart diseases, stroke and chronic kidney diseases are all related to high $\mathrm{BP}$ and a cluster of metabolic factors such as insulin resistance, obesity-associated dyslipidemia and DM2 [36]. Cardiac NPs or their NTpro-peptides are widely applied as $\mathrm{CV}$ biomarkers in epidemiological studies as well as in the clinical routine setting [76]. In common clinical practice, NTpro-BNP and BNP tests are recommended by guidelines for diagnosis, prognosis and guided therapy of $\mathrm{HF}$, and also for risk stratification in patients with acute coronary syndromes [77, 78]. They have a diagnostic and prognostic relevance not only in adult patients, but also in elderly and very elderly populations [79]. In presence of HF, both NT-proBNP and BNP levels are increased. NT-proBNP is not a substrate for neprilysin and remains an accurate marker of HF even in the setting of neprilysin inhibition. On the contrary, BNP levels tend to increase under neprilysin inhibition and then it is not useful to evaluate prognosis of HF patients treated with neprilysin inhibitor [80].

Several studies showed an important role of NPs also in the global CV risk assessment, even in absence of known clinical HF [81]. NT-proANP and NT-proBNP are well established markers of prevalent CVDs and helpful outcome predictors in patients with established CVD [63] such as stable and unstable coronary artery disease [82-84]. In coronary artery disease, Barbato et al. showed a parallel increase in circulating NPs levels at increasing coronary stenosis, until reaching a plateau at the highest degree of vessel stenosis, regardless the underlying myocardial disease [85].

Given the close relationship with $\mathrm{CV}$ hemodynamic and structure, NPs levels represent a very sensitive marker of $\mathrm{CV}$ risk also in general population [86-88], in which NTproBNP appeared to be superior to BNP for predicting $\mathrm{CV}$ events [89]. A recent meta-analysis on data from 95,617 participants without a known history of CVD, found that NT-proBNP strongly predicted first-onset HF, augmented 
risk for coronary heart disease and stroke, and $\mathrm{CV}$ deaths. Moreover, NT-proBNP concentration measurement improved the $\mathrm{CV}$ risk discrimination in addition to the classic CV risk factors (age, sex, smoking, systolic BP, history of diabetes), suggesting a possible role of NPs assays in the $\mathrm{CV}$ risk assessment in primary prevention [81, 90]. Similarly, in DM2 populations, NT-proBNP showed the higher hazard ratios for risk of major $\mathrm{CV}$ events during a follow up of 11 years, and the largest improvement in discriminatory power beyond the traditional risk factors, compared to other 22 novel biomarkers involved in several pathophysiological pathways [91].

Therefore, in contrast with the notion that NT-proBNP concentration is predominantly a cardiac biomarker, it predicts also cerebrovascular events and poorer prognosis after them [92]. Higher NPs levels showed a positive association with future risk of ischemic stroke, both in higher CV risk populations [93] and in general populations [94]. NT-proBNP levels may reflect adverse hemodynamic alterations due to ventricular dysfunction, while NTproANP levels may better reflect vascular dysfunction [84]. In fact, it is well documented that ANP affects proliferation, angiogenesis and contractility of the vascular wall cells as well as endothelial function maintenance [95-97]. Notably, it has been observed that physiological concentrations of ANP may promote endothelial cell regeneration after atherosclerotic damage and overexpression of ANP has also been evaluated as a possible treatment for intima lesion formation [98, 99].

Increased arterial stiffness and higher $\mathrm{CV}$ risk were found to be associated with lower diastolic BP levels in isolated systolic hypertension. Recently, an association between BNP levels and diastolic BP values was found. In fact, higher BNP levels were linked with lower diastolic BP. Therefore, NPs levels may be used even to individualize BP targets in relation to varying CV risk, thus assisting in stratification of individual clinical decisions and improving management of hypertensives at a greater CV risk [100].

\subsection{Cardiac NPs and Mortality}

The associations between cardiac NPs system and all the above-mentioned cardiometabolic aspects relate to serious clinical implications such as CV events and mortality. The association between NPs levels and mortality has been extensively evaluated $[86,101]$. In the offspring study from the Framingham population, NPs levels significantly predicted mortality from $\mathrm{CV}$ causes in apparently healthy subjects [101]. In a recent meta-analysis on 25,715 participants, elevated NT-proBNP levels appeared to be independently associated with increased risk for $\mathrm{CV}$ and all-cause mortality in the general population. Individuals in the highest NT-proBNP concentration significantly increased 3.77-fold CV mortality and 2.44-fold all-cause mortality, even after adjustment for the traditional $\mathrm{CV}$ risk factors. In this setting, authors stated that higher NTproBNP levels might reflect the degree of systemic atherosclerosis and/or an unknown initial cardiac overload/ stretch [102]. NT-proBNP is strongly associated with allcause mortality also in hypertensive population. Paget et al. have demonstrated that plasma NT-proBNP levels $\geq 133 \mathrm{pg} / \mathrm{mL}$ were associated with a threefold increase of the risk of death in comparison with levels $<50.8 \mathrm{pg} / \mathrm{mL}$, even after adjustment for confounders. Moreover, NTproBNP resulted to be a stronger prognostic marker than ECG and its dosage has been proposed as first test for the CV stratification instead of ECG [103]. Predictive value of elevated BNP levels on mortality has been tested also in several clinical scenarios different from CVD, such as chronic obstructive pulmonary disease and end stage renal disease [104]. These conditions are characterized by a lowgrade chronic inflammation [105] and often coexist with MetS and CVD [106]. Given the beneficial role of NPs on energy expenditure and low-grade chronic inflammation, we think that lipid and glucose NPs-mediated metabolism may play a protective role also in these conditions.

\section{Summary, Conclusion and Perspectives}

Despite considerable progress in Medicine, CVDs still represent the main cause of morbidity and mortality worldwide. In the last decades, the increased knowledge about cardiac NPs system has sharply clarified their important role in CVDs, linking glucose and lipid dysmetabolism with higher $\mathrm{BP}$ as well as $\mathrm{CV}$ events and mortality. In the next future, NPs may play a crucial role in the management of CVDs as diagnostic/prognostic biomarkers and, using tailored cardiac NPs, as possible therapeutic agents [107]. It is very likely that a clearance receptor (NPRC)-blocking drug will improve both metabolic and CV disorders. The relevance of cardiac NPs in cardiometabolic diseases appears to increase year-by-year in clinical practice. The main obstacle in the correct interpretations of circulating NPs values is represented by the continuous resetting between ANP and BNP peripheral activities and cardiac secretion, both in physiological and pathological conditions. This requires the contemporary assessment of many cardiac parameters, including diastolic function and right heart parameters, as well as renal function together with cardiac NPs assays. Only in some HF patients, the massive NPs secretion appears to overcome the functional cardiac resetting, leading to important consequences including cardiac cachexia [108]. Keeping in mind these practical limitations, the predictive role of 
cardiac NPs may also be useful to detect subclinical damage in asymptomatic individuals, thus improving $\mathrm{CV}$ risk stratification and prevention. The multiple effects exerted by NPs have raised the interest for the development of new therapies for the treatment of extremely frequent conditions such as hypertension and HF. Therefore, the development and administration of recombinant NPs first (Nesiritide, Carperitide and Ularitide) and then of designer NPs (Vasonatrin, Cenderitide, ANX042 and ZD100), as well as the recent clinical use of a new class of combination drugs, which inhibits both angiotensin II receptor and neprilysin activities (ARNI), led to encouraging results, in terms of efficacy and safety in different settings [107]. It is important to remember that ARNI, by reducing NPs degradation and angiotensin II activity, is not only an innovative and landmarking drug in HF patients [76, 109], but it is also a potent antihypertensive agent [110]. It is hoped that pandemic conditions, such as hypertension, obesity and MetS, could benefit from a NPs-based approach, both for diagnosis and for treatment, in the near future.

\section{Acknowledgments None.}

\section{Compliance with Ethical Standards}

Funding All authors report no specific funding in relation to this research.

Conflict of Interest All authors report no conflicts of interest to disclose.

Ethical Approval This article does not contain any studies with human participants or animals performed by any of the authors.

Open Access This article is distributed under the terms of the Creative Commons Attribution-NonCommercial 4.0 International License (http://creativecommons.org/licenses/by-nc/4.0/), which permits any noncommercial use, distribution, and reproduction in any medium, provided you give appropriate credit to the original author(s) and the source, provide a link to the Creative Commons license, and indicate if changes were made.

\section{References}

1. Chobanian AV. Shattuck Lecture. The hypertension paradoxmore uncontrolled disease despite improved therapy. N Engl J Med. 2009;361(9):878-87.

2. Tocci G, Nati G, Cricelli C, Parretti D, Lapi F, Ferrucci A, Borghi C, Volpe M. Prevalence and control of hypertension in the general practice in Italy: updated analysis of a large database. J Hum Hypertens. 2017;31(4):258-62.

3. Ng M, Fleming T, Robinson M, Thomson B, Graetz N, Margono C, Mullany EC, Biryukov S, Abbafati C, Abera SF, Abraham JP, Abu-Rmeileh NM, Achoki T, AlBuhairan FS, Alemu ZA, Alfonso R, Ali MK, Ali R, Guzman NA, Ammar W, Anwari P, Banerjee A, Barquera S, Basu S, Bennett DA, Bhutta Z, Blore J,
Cabral N, Nonato IC, Chang JC, Chowdhury R, Courville KJ, Criqui MH, Cundiff DK, Dabhadkar KC, Dandona L, Davis A, Dayama A, Dharmaratne SD, Ding EL, Durrani AM, Esteghamati A, Farzadfar F, Fay DF, Feigin VL, Flaxman A, Forouzanfar MH, Goto A, Green MA, Gupta R, Hafezi-Nejad N, Hankey GJ, Harewood HC, Havmoeller R, Hay S, Hernandez L, Husseini A, Idrisov BT, Ikeda N, Islami F, Jahangir E, Jassal SK, Jee SH, Jeffreys M, Jonas JB, Kabagambe EK, Khalifa SE, Kengne AP, Khader YS, Khang YH, Kim D, Kimokoti RW, Kinge JM, Kokubo Y, Kosen S, Kwan G, Lai T, Leinsalu M, Li Y, Liang X, Liu S, Logroscino G, Lotufo PA, Lu Y, Ma J, Mainoo NK, Mensah GA, Merriman TR, Mokdad AH, Moschandreas J, Naghavi M, Naheed A, Nand D, Narayan KM, Nelson EL, Neuhouser ML, Nisar MI, Ohkubo T, Oti SO, Pedroza A, Prabhakaran D, Roy N, Sampson U, Seo H, Sepanlou SG, Shibuya K, Shiri R, Shiue I, Singh GM, Singh JA, Skirbekk V, Stapelberg NJ, Sturua L, Sykes BL, Tobias M, Tran BX, Trasande L, Toyoshima H, van de Vijver S, Vasankari TJ, Veerman JL, Velasquez-Melendez G, Vlassov VV, Vollset SE, Vos T, Wang C, Wang X, Weiderpass E, Werdecker A, Wright JL, Yang YC, Yatsuya H, Yoon J, Yoon SJ, Zhao Y, Zhou M, Zhu S, Lopez AD, Murray CJ, Gakidou E. Global, regional, and national prevalence of overweight and obesity in children and adults during 1980-2013: a systematic analysis for the Global Burden of Disease Study 2013. Lancet. 2014;384(9945):766-81.

4. Guariguata L, Whiting DR, Hambleton I, Beagley J, Linnenkamp U, Shaw JE. Global estimates of diabetes prevalence for 2013 and projections for 2035. Diabetes Res Clin Pract. 2014;103(2):137-49.

5. Landsberg L, Aronne LJ, Beilin LJ, Burke V, Igel LI, LloydJones D, Sowers J. Obesity-related hypertension: pathogenesis, cardiovascular risk, and treatment: a position paper of The Obesity Society and the American Society of Hypertension. J Clin Hypertens (Greenwich). 2013;15(1):14-33.

6. Woodard GE, Rosado JA. Natriuretic peptides in vascular physiology and pathology. Int Rev Cell Mol Biol. 2008;268:59-93.

7. Sarzani R, Salvi F, Dessì-Fulgheri P, Rappelli A. Renin-angiotensin system, natriuretic peptides, obesity, metabolic syndrome, and hypertension: an integrated view in humans. J Hypertens. 2008;26(5):831-43.

8. Kangawa K, Fukuda A, Minamino N, Matsuo H. Purification and complete amino acid sequence of beta-rat atrial natriuretic polypeptide (beta-rANP) of 5,000 daltons. Biochem Biophys Res Commun. 1984;119(3):933-40.

9. Sudoh T, Kangawa K, Minamino N, Matsuo H. A new natriuretic peptide in porcine brain. Nature. 1988;332(6159):78-81.

10. Sudoh T, Minamino N, Kangawa K, Matsuo H. C-type natriuretic peptide (CNP): a new member of natriuretic peptide family identified in porcine brain. Biochem Biophys Res Commun. 1990;168(2):863-70.

11. Bonow RO. New insights into the cardiac natriuretic peptides. Circulation. 1996;93(11):1946-50.

12. Hama N, Itoh H, Shirakami G, Nakagawa O, Suga S, Ogawa Y, Masuda I, Nakanishi K, Yoshimasa T, Hashimoto Y, Yamaguchi M, Hori R, Yasue H, Nakao K. Rapid ventricular induction of brain natriuretic peptide gene expression in experimental acute myocardial infarction. Circulation. 1995;92(6):1558-64.

13. Tate S, Griem A, Durbin-Johnson B, Watt C, Schaefer S. Marked elevation of B-type natriuretic peptide in patients with heart failure and preserved ejection fraction. $\mathrm{J}$ Biomed Res. 2014;28(4):255-61.

14. Wiese S, Breyer T, Dragu A, Wakili R, Burkard T, SchmidtSchweda S, Füchtbauer EM, Dohrmann U, Beyersdorf F, Radicke D, Holubarsch CJ. Gene expression of brain natriuretic 
peptide in isolated atrial and ventricular human myocardium: influence of angiotensin II and diastolic fiber length. Circulation. 2000;102(25):3074-9.

15. Yoshimura M, Yasue H, Okumura K, Ogawa H, Jougasaki M, Mukoyama M, Nakao K, Imura H. Different secretion patterns of atrial natriuretic peptide and brain natriuretic peptide in patients with congestive heart failure. Circulation. 1993;87(2):464-9.

16. Doyama K, Fukumoto M, Takemura G, Tanaka M, Oda T, Hasegawa K, Inada T, Ohtani S, Fujiwara T, Itoh H, Nakao K, Sasayama S, Fujiwara H. Expression and distribution of brain natriuretic peptide in human right atria. J Am Coll Cardiol. 1998;32(7):1832-8.

17. Sumida H, Yasue H, Yoshimura M, Okumura K, Ogawa H, Kugiyama K, Matsuyama K, Kikuta K, Morita E, Nakao K. Comparison of secretion pattern between A-type and B-type natriuretic peptides in patients with old myocardial infarction. J Am Coll Cardiol. 1995;25(5):1105-10.

18. Volpe M. Natriuretic peptides and cardio-renal disease. Int $\mathbf{J}$ Cardiol. 2014;176(3):630-9.

19. Waldman SA, Rapoport RM, Murad F. Atrial natriuretic factor selectively activates particulate guanylate cyclase and elevates cyclic GMP in rat tissues. J Biol Chem. 1984;259(23):14332-4.

20. Song DL, Kohse KP, Murad F. Brain natriuretic factor. Augmentation of cellular cyclic GMP, activation of particulate guanylate cyclase and receptor binding. FEBS Lett. 1988;232(1):125-9.

21. Sarzani R, Dessì-Fulgheri P, Paci VM, Espinosa E, Rappelli A. Expression of natriuretic peptide receptors in human adipose and other tissues. J Endocrinol Invest. 1996;19(9):581-5.

22. Kenny AJ, Bourne A, Ingram J. Hydrolysis of human and pig brain natriuretic peptides, urodilatin, C-type natriuretic peptide and some C-receptor ligands by endopeptidase-24.11. Biochem J. 1993;291(1):83-8.

23. Dessì-Fulgheri P, Sarzani R, Tamburrini P, Moraca A, Espinosa E, Cola G, Giantomassi L, Rappelli A. Plasma atrial natriuretic peptide and natriuretic peptide receptor gene expression in adipose tissue of normotensive and hypertensive obese patients. J Hypertens. 1997;15:1695-9.

24. Schlueter N, de Sterke A, Willmes DM, Spranger J, Jordan J, Birkenfeld AL. Metabolic actions of natriuretic peptides and therapeutic potential in the metabolic syndrome. Pharmacol Ther. 2014;144(1):12-27.

25. Mukoyama M, Nakao K, Hosoda K, Suga S, Saito Y, Ogawa Y, Shirakami G, Jougasaki M, Obata K, Yasue H. Brain natriuretic peptide as a novel cardiac hormone in humans. Evidence for an exquisite dual natriuretic peptide system, atrial natriuretic peptide and brain natriuretic peptide. J Clin Invest. 1991;87(4):1402-12.

26. Nakao K, Sugawara A, Morii N, Sakamoto M, Yamada T, Itoh H, Shiono S, Saito Y, Nishimura K, Ban T, et al. The pharmacokinetics of alpha-human atrial natriuretic polypeptide in healthy subjects. Eur J Clin Pharmacol. 1986;31:101-3.

27. Weber M, Hamm C. Role of B-type natriuretic peptide (BNP) and NT-proBNP in clinical routine. Heart. 2006;92(6):843-9.

28. Minamino N, Makino Y, Tateyama H, Kangawa K, Matsuo H. Characterization of immunoreactive human C-type natriuretic peptide in brain and heart. Biochem Biophys Res Commun. 1991;179(1):535-42.

29. Suga S, Nakao K, Itoh H, Komatsu Y, Ogawa Y, Hama N, Imura $\mathrm{H}$. Endothelial production of C-type natriuretic peptide and its marked augmentation by transforming growth factor-beta. Possible existence of "vascular natriuretic peptide system". J Clin Invest. 1992;90(3):1145-449.

30. Patel P, Chen HH. Natriuretic peptides as a novel target in resistant hypertension. Curr Hypertens Rep. 2015;17(3):18.
31. Sarzani R, Bordicchia M, Spannella F, Dessì-Fulgheri P, Fedecostante M. Hypertensive heart disease and obesity: a complex interaction between hemodynamic and not hemodynamic factors. High Blood Press Cardiovasc Prev. 2014;21(2):81-7.

32. Bordicchia M, Ceresiani M, Pavani M, Minardi D, Polito M, Wabitsch M, Cannone V, Burnett JC Jr, Dessì-Fulgheri P, Sarzani R. Insulin/glucose induces natriuretic peptide clearance receptor in human adipocytes: a metabolic link with the cardiac natriuretic pathway. Am J Physiol Regul Integr Comp Physiol. 2016;311(1):R104-14.

33. Sarzani R, Guerra F, Mancinelli L, Buglioni A, Franchi E, Dessi-Fulgheri P. Plasma aldosterone is increased in class 2 and 3 obese essential hypertensive patients despite drug treatment. Am J Hypertens. 2012;25(7):818-26.

34. Engeli S, Negrel R, Sharma AM. Physiology and pathophysiology of the adipose tissue renin-angiotensin system. Hypertension. 2000;35(6):1270-7.

35. Shi SJ, Nguyen HT, Sharma GD, Navar LG, Pandey KN. Genetic disruption of atrial natriuretic peptide receptor-A alters renin and angiotensin II levels. Am J Physiol Renal Physiol. 2001;281(4):F665-73.

36. Heymsfield SB, Wadden TA. Mechanisms, pathophysiology, and management of obesity. $\mathrm{N}$ Engl $\mathrm{J}$ Med. 2017;376(3):254-66.

37. Goossens GH, Blaak EE, Arner P, Saris WH, van Baak MA. Angiotensin II: a hormone that affects lipid metabolism in adipose tissue. Int J Obes (Lond). 2007;31(2):382-4.

38. Sarzani R, Marcucci P, Salvi F, Bordicchia M, Espinosa E, Mucci L, Lorenzetti B, Minardi D, Muzzonigro G, Dessì-Fulgheri P, Rappelli A. Angiotensin II stimulates and atrial natriuretic peptide inhibits human visceral adipocyte growth. Int J Obes (Lond). 2008;32(2):259-67.

39. Sengenès C, Berlan M, De Glisezinski I, Lafontan M, Galitzky J. Natriuretic peptides: a new lipolytic pathway in human adipocytes. FASEB J. 2000;14(10):1345-51.

40. Bordicchia M, Liu D, Amri EZ, Ailhaud G, Dessì-Fulgheri P, Zhang C, Takahashi N, Sarzani R, Collins S. Cardiac natriuretic peptides act via p38 MAPK to induce the brown fat thermogenic program in mouse and human adipocytes. J Clin Invest. 2012;122(3):1022-36.

41. Miyashita K, Itoh H, Tsujimoto H, Tamura N, Fukunaga Y, Sone M, Yamahara K, Taura D, Inuzuka M, Sonoyama T, Nakao K. Natriuretic peptides/cGMP/cGMP-dependent protein kinase cascades promote muscle mitochondrial biogenesis and prevent obesity. Diabetes. 2009;58(12):2880-92.

42. Shu L, Hoo RL, Wu X, Pan Y, Lee IP, Cheong LY, Bornstein SR, Rong X, Guo J, Xu A. A-FABP mediates adaptive thermogenesis by promoting intracellular activation of thyroid hormones in brown adipocytes. Nat Commun. 2017;8:14147.

43. Nakatsuji H, Maeda N, Hibuse T, Hiuge A, Hirata A, Kuroda Y, Kishida K, Kihara S, Funahashi T, Shimomura I. Reciprocal regulation of natriuretic peptide receptors by insulin in adipose cells. Biochem Biophys Res Commun. 2010;392(1):100-5.

44. Pivovarova O, Gögebakan Ö, Klöting N, Sparwasser A, Weickert MO, Haddad I, Nikiforova VJ, Bergmann A, Kruse M, Seltmann AC, Blüher M, Pfeiffer AF, Rudovich N. Insulin upregulates natriuretic peptide clearance receptor expression in the subcutaneous fat depot in obese subjects: a missing link between CVD risk and obesity? J Clin Endocrinol Metab. 2012;97(5):E731-9.

45. Sarzani R, Paci VM, Zingaretti CM, Pierleoni C, Cinti S, Cola G, Rappelli A, Dessì-Fulgheri P. Fasting inhibits natriuretic peptides clearance receptor expression in rat adipose tissue. J Hypertens. 1995;13(11):1241-6.

46. Dessì-Fulgheri P, Sarzani R, Serenelli M, Tamburrini P, Spagnolo D, Giantomassi L, Espinosa E, Rappelli A. Low calorie diet 
enhances renal, hemodynamic, and humoral effects of exogenous atrial natriuretic peptide in obese hypertensives. Hypertension. 1999;33(2):658-62.

47. Jordan J, Birkenfeld AL. Comment on: Vila et al. B-type natriuretic peptide modulates ghrelin, hunger, and satiety in healthy men. Diabetes. 2012;61:2592-6.

48. Tsukamoto O, Fujita M, Kato M, Yamazaki S, Asano Y, Ogai A, Okazaki H, Asai M, Nagamachi Y, Maeda N, Shintani Y, Minamino T, Asakura M, Kishimoto I, Funahashi T, Tomoike $\mathrm{H}$, Kitakaze M. Natriuretic peptides enhance the production of adiponectin in human adipocytes and in patients with chronic heart failure. J Am Coll Cardiol. 2009;53(22):2070-7.

49. Graja A, Schulz TJ. Mechanisms of aging-related impairment of brown adipocyte development and function. Gerontology. 2015;61(3):211-7.

50. Goodpaster BH, Park SW, Harris TB, Kritchevsky SB, Nevitt M, Schwartz AV, Simonsick EM, Tylavsky FA, Visser M, Newman AB. The loss of skeletal muscle strength, mass, and quality in older adults: the health, aging and body composition study. J Gerontol A Biol Sci Med Sci. 2006;61(10):1059-64.

51. Huang WS, Lee MS, Perng HW, Yang SP, Kuo SW, Chang HD. Circulating brain natriuretic peptide values in healthy men before and after exercise. Metabolism. 2002;51(11):1423-6.

52. Musani SK, Vasan RS, Bidulescu A, Liu J, Xanthakis V, Sims M, Gawalapu RK, Samdarshi TE, Steffes M, Taylor HA, Fox ER. Aldosterone, C-reactive protein, and plasma B-type natriuretic peptide are associated with the development of metabolic syndrome and longitudinal changes in metabolic syndrome components: findings from the Jackson Heart Study. Diabetes Care. 2013;36(10):3084-92.

53. Magnusson M, Jujic A, Hedblad B, Engström G, Persson M, Struck J, Morgenthaler NG, Nilsson P, Newton-Cheh C, Wang TJ, Melander O. Low plasma level of atrial natriuretic peptide predicts development of diabetes: the prospective Malmo Diet and Cancer study. J Clin Endocrinol Metab. 2012;97(2):638-45.

54. Lazo M, Young JH, Brancati FL, Coresh J, Whelton S, Ndumele CE, Hoogeveen R, Ballantyne CM, Selvin E. NH2-terminal probrain natriuretic peptide and risk of diabetes. Diabetes. 2013;62(9):3189-93.

55. Pfister R, Sharp S, Luben R, Welsh P, Barroso I, Salomaa V, Meirhaeghe A, Khaw KT, Sattar N, Langenberg C, Wareham NJ. Mendelian randomization study of B-type natriuretic peptide and type 2 diabetes: evidence of causal association from population studies. PLoS Med. 2011;8(10):e1001112.

56. Kirkman MS, Briscoe VJ, Clark N, Florez H, Haas LB, Halter JB, Huang ES, Korytkowski MT, Munshi MN, Odegard PS, Pratley RE, Swift CS. Diabetes in older adults. Diabetes Care. 2012;35(12):2650-64

57. Gruden G, Landi A, Bruno G. Natriuretic peptides, heart, and adipose tissue: new findings and future developments for diabetes research. Diabetes Care. 2014;37(11):2899-908.

58. Khan AM, Cheng S, Magnusson M, Larson MG, Newton-Cheh C, McCabe EL, Coviello AD, Florez JC, Fox CS, Levy D, Robins SJ, Arora P, Bhasin S, Lam CS, Vasan RS, Melander O, Wang TJ. Cardiac natriuretic peptides, obesity, and insulin resistance: evidence from two community-based studies. J Clin Endocrinol Metab. 2011;96(10):3242-9.

59. Cannone V, Cefalu' AB, Noto D, Scott CG, Bailey KR, Cavera G, Pagano M, Sapienza M, Averna MR, Burnett JC Jr. The atrial natriuretic peptide genetic variant rs5068 is associated with a favorable cardiometabolic phenotype in a Mediterranean population. Diabetes Care. 2013;36(9):2850-6.

60. Sarzani R, Strazzullo P, Salvi F, Iacone R, Pietrucci F, Siani A, Barba G, Gerardi MC, Dessi-Fulgheri P, Rappelli A. Natriuretic peptide clearance receptor alleles and susceptibility to abdominal adiposity. Obes Res. 2004;12(2):351-6.
61. International Consortium for Blood Pressure Genome-Wide Association Studies, Ehret GB, Munroe PB, Rice KM, Bochud M, Johnson AD, Chasman DI, Smith AV, Tobin MD, Verwoert GC, Hwang SJ, Pihur V, Vollenweider P, O'Reilly PF, Amin N, Bragg-Gresham JL, Teumer A, Glazer NL, Launer L, Zhao JH, Aulchenko Y, Heath S, Sõber S, Parsa A, Luan J, Arora P, Dehghan A, Zhang F, Lucas G, Hicks AA, Jackson AU, Peden JF, Tanaka T, Wild SH, Rudan I, Igl W, Milaneschi Y, Parker AN, Fava C, Chambers JC, Fox ER, Kumari M, Go MJ, van der Harst P, Kao WH, Sjögren M, Vinay DG, Alexander M, Tabara Y, Shaw-Hawkins S, Whincup PH, Liu Y, Shi G, Kuusisto J, Tayo B, Seielstad M, Sim X, Nguyen KD, Lehtimäki T, Matullo G, Wu Y, Gaunt TR, Onland-Moret NC, Cooper MN, Platou CG, Org E, Hardy R, Dahgam S, Palmen J, Vitart V, Braund PS, Kuznetsova T, Uiterwaal CS, Adeyemo A, Palmas W, Campbell H, Ludwig B, Tomaszewski M, Tzoulaki I, Palmer ND, CARDIoGRAM Consortium, CKDGen Consortium, KidneyGen Consortium, EchoGen consortium, CHARGE-HF Consortium, Aspelund T, Garcia M, Chang YP, O'Connell JR, Steinle NI, Grobbee DE, Arking DE, Kardia SL, Morrison AC, Hernandez D, Najjar S, McArdle WL, Hadley D, Brown MJ, Connell JM, Hingorani AD, Day IN, Lawlor DA, Beilby JP, Lawrence RW, Clarke R, Hopewell JC, Ongen H, Dreisbach AW, Li Y, Young JH, Bis JC, Kähönen M, Viikari J, Adair LS, Lee NR, Chen MH, Olden M, Pattaro C, Bolton JA, Köttgen A, Bergmann S, Mooser V, Chaturvedi N, Frayling TM, Islam M, Jafar TH, Erdmann J, Kulkarni SR, Bornstein SR, Grässler J, Groop L, Voight BF, Kettunen J, Howard P, Taylor A, Guarrera S, Ricceri F, Emilsson V, Plump A, Barroso I, Khaw KT, Weder AB, Hunt SC, Sun YV, Bergman RN, Collins FS, Bonnycastle LL, Scott LJ, Stringham HM, Peltonen L, Perola M, Vartiainen E, Brand SM, Staessen JA, Wang TJ, Burton PR, Soler Artigas M, Dong Y, Snieder H, Wang X, Zhu H, Lohman KK, Rudock ME, Heckbert SR, Smith NL, Wiggins KL, Doumatey A, Shriner D, Veldre G, Viigimaa M, Kinra S, Prabhakaran D, Tripathy V, Langefeld CD, Rosengren A, Thelle DS, Corsi AM, Singleton A, Forrester T, Hilton G, McKenzie CA, Salako T, Iwai N, Kita Y, Ogihara T, Ohkubo T, Okamura T, Ueshima H, Umemura S, Eyheramendy S, Meitinger T, Wichmann HE, Cho YS, Kim HL, Lee JY, Scott J, Sehmi JS, Zhang W, Hedblad B, Nilsson P, Smith GD, Wong A, Narisu N, Stančáková A, Raffel LJ, Yao J, Kathiresan S, O'Donnell CJ, Schwartz SM, Ikram MA, Longstreth WT Jr, Mosley TH, Seshadri S, Shrine NR, Wain LV, Morken MA, Swift AJ, Laitinen J, Prokopenko I, Zitting P, Cooper JA, Humphries SE, Danesh J, Rasheed A, Goel A, Hamsten A, Watkins H, Bakker SJ, van Gilst WH, Janipalli CS, Mani KR, Yajnik CS, Hofman A, Mattace-Raso FU, Oostra BA, Demirkan A, Isaacs A, Rivadeneira F, Lakatta EG, Orru M, Scuteri A, Ala-Korpela M, Kangas AJ, Lyytikäinen LP, Soininen P, Tukiainen T, Würtz P, Ong RT, Dörr M, Kroemer HK, Völker U, Völzke H, Galan P, Hercberg S, Lathrop M, Zelenika D, Deloukas P, Mangino M, Spector TD, Zhai G, Meschia JF, Nalls MA, Sharma P, Terzic J, Kumar MV, Denniff M, Zukowska-Szczechowska E, Wagenknecht LE, Fowkes FG, Charchar FJ, Schwarz PE, Hayward C, Guo X, Rotimi C, Bots ML, Brand E, Samani NJ, Polasek O, Talmud PJ, Nyberg F, Kuh D, Laan M, Hveem K, Palmer LJ, van der Schouw YT, Casas JP, Mohlke KL, Vineis P, Raitakari O, Ganesh SK, Wong TY, Tai ES, Cooper RS, Laakso M, Rao DC, Harris TB, Morris RW, Dominiczak AF, Kivimaki M, Marmot MG, Miki T, Saleheen D, Chandak GR, Coresh J, Navis G, Salomaa V, Han BG, Zhu X, Kooner JS, Melander O, Ridker PM, Bandinelli S, Gyllensten UB, Wright AF, Wilson JF, Ferrucci L, Farrall M, Tuomilehto J, Pramstaller PP, Elosua R, Soranzo N, Sijbrands EJ, Altshuler D, Loos RJ, Shuldiner AR, Gieger C, Meneton P, Uitterlinden AG, Wareham NJ, Gudnason V, Rotter JI, Rettig R, Uda M, Strachan 
DP, Witteman JC, Hartikainen AL, Beckmann JS, Boerwinkle E, Vasan RS, Boehnke M, Larson MG, Järvelin MR, Psaty BM, Abecasis GR, Chakravarti A, Elliott P, van Duijn CM, NewtonCheh C, Levy D, Caulfield MJ, Johnson T. International Consortium for Blood Pressure Genome-Wide Association Studies. Genetic variants in novel pathways influence blood pressure and cardiovascular disease risk. Nature. 2011;478(7367):103-9.

62. Holditch SJ, Schreiber CA, Nini R, Tonne JM, Peng KW, Geurts A, Jacob HJ, Burnett JC, Cataliotti A, Ikeda Y. B-type natriuretic peptide deletion leads to progressive hypertension, associated organ damage, and reduced survival: novel model for human hypertension. Hypertension. 2015;66(1):199-210.

63. Volpe M, Rubattu S, Burnett J Jr. Natriuretic peptides in cardiovascular diseases: current use and perspectives. Eur Heart J. 2014;35(7):419-25.

64. Newton-Cheh C, Larson MG, Vasan RS, Levy D, Bloch KD, Surti A, Guiducci C, Kathiresan S, Benjamin EJ, Struck J, Morgenthaler NG, Bergmann A, Blankenberg S, Kee F, Nilsson P, Yin X, Peltonen L, Vartiainen E, Salomaa V, Hirschhorn JN, Melander O, Wang TJ. Association of common variants in NPPA and NPPB with circulating natriuretic peptides and blood pressure. Nat Genet. 2009;41(3):348-53.

65. Cannone V, Boerrigter G, Cataliotti A, Costello-Boerrigter LC, Olson TM, McKie PM, Heublein DM, Lahr BD, Bailey KR, Averna M, Redfield MM, Rodeheffer RJ, Burnett JC Jr. A genetic variant of the atrial natriuretic peptide gene is associated with cardiometabolic protection in the general community. J Am Coll Cardiol. 2011;58(6):629-36.

66. Belluardo $P$, Cataliotti A, Bonaiuto L, Giuffrè E, Maugeri E, Noto P, Orlando G, Raspa G, Piazza B, Babuin L, Chen HH, Martin FL, McKie PM, Heublein DM, Burnett JC Jr, Malatino LS. Lack of activation of molecular forms of the BNP system in human grade 1 hypertension and relationship to cardiac hypertrophy. Am J Physiol Heart Circ Physiol. 2006;291(4):H1529-35.

67. Macheret F, Heublein D, Costello-Boerrigter LC, Boerrigter G, McKie P, Bellavia D, Mangiafico S, Ikeda Y, Bailey K, Scott CG, Sandberg S, Chen HH, Malatino L, Redfield MM, Rodeheffer R, Burnett $\mathrm{J}$ Jr, Cataliotti A. Human hypertension is characterized by a lack of activation of the antihypertensive cardiac hormones ANP and BNP. J Am Coll Cardiol. 2012;60(16):1558-65.

68. Ruilope LM, Dukat A, Böhm M, Lacourcière Y, Gong J, Lefkowitz MP. Blood-pressure reduction with LCZ696, a novel dual-acting inhibitor of the angiotensin II receptor and neprilysin: a randomised, double-blind, placebo-controlled, active comparator study. Lancet. 2010;375(9722):1255-66.

69. Matsukawa N, Grzesik WJ, Takahashi N, Pandey KN, Pang S, Yamauchi M, Smithies O. The natriuretic peptide clearance receptor locally modulates the physiological effects of the natriuretic peptide system. Proc Natl Acad Sci USA. 1999;96(13):7403-8.

70. Rubattu S, Bigatti G, Evangelista A, Lanzani C, Stanzione R, Zagato L, Manunta P, Marchitti S, Venturelli V, Bianchi G, Volpe M, Stella P. Association of atrial natriuretic peptide and type a natriuretic peptide receptor gene polymorphisms with left ventricular mass in human essential hypertension. J Am Coll Cardiol. 2006;48(3):499-505.

71. Pitzalis MV, Sarzani R, Dessì-Fulgheri P, Iacoviello M, Forleo C, Lucarelli K, Pietrucci F, Salvi F, Sorrentino S, Romito R, Guida P, Rappelli A, Rizzon P. Allelic variants of natriuretic peptide receptor genes are associated with family history of hypertension and cardiovascular phenotype. J Hypertens. 2003;21(8):1491-6.

72. Rubattu S, Sciarretta S, Volpe M. Atrial natriuretic peptide gene variants and circulating levels: implications in cardiovascular diseases. Clin Sci (Lond). 2014;127:1-13.
73. Volpe M, Rubattu S. Novel insights into the mechanisms regulating pro-atrial natriuretic peptide cleavage in the heart and blood pressure regulation: proprotein convertase subtilisin/kexin 6 is the corin activating enzyme. Circ Res. 2016;118:196-8.

74. Yasumoto K, Takata M, Ueno H, Tomita S, Tomoda F, Inoue H. Relation of plasma brain and atrial natriuretic peptides to left ventricular geometric patterns in essential hypertension. Am J Hypertens. 1999;12(9Pt1):921-4.

75. Demerath T, Staffel J, Schreiber A, Valletta D, Schweda F. Natriuretic peptides buffer renin-dependent hypertension. Am J Physiol Ren Physiol. 2014;306(12):F1489-98.

76. Volpe M, Carnovali M, Mastromarino V. The natriuretic peptides system in the pathophysiology of heart failure: from molecular basis to treatment. Clin Sci (Lond). 2016;130(2):57-77.

77. Ponikowski P, Voors AA, Anker SD, Bueno H, Cleland JG, Coats AJ, Falk V, González-Juanatey JR, Harjola VP, Jankowska EA, Jessup M, Linde C, Nihoyannopoulos P, Parissis JT, Pieske B, Riley JP, Rosano GM, Ruilope LM, Ruschitzka F, Rutten FH, van der Meer P, Authors/Task Force Members. 2016 ESC Guidelines for the diagnosis and treatment of acute and chronic heart failure: The Task Force for the diagnosis and treatment of acute and chronic heart failure of the European Society of Cardiology (ESC) developed with the special contribution of the Heart Failure Association (HFA) of the ESC. Eur Heart J. 2016;37(27):2129-200.

78. Morrow DA, Cannon CP, Jesse RL, Newby LK, Ravkilde J, Storrow AB, Wu AH, Christenson RH, National Academy of Clinical Biochemistry. National academy of clinical biochemistry laboratory medicine practice guidelines: clinical characteristics and utilization of biochemical markers of acute coronary syndromes. Circulation. 2007;115:e356-75.

79. Sarzani R, Spannella F, Giulietti F, Fedecostante M, Giordano P, Gattafoni P, Espinosa E, Busco F, Piccinini G, Dessì-Fulgheri P. NT-proBNP and its correlation with in-hospital mortality in the very elderly without an admission diagnosis of heart failure. PLoS One. 2016;11(4):e0153759.

80. Jhund PS, McMurray JJ. The neprilysin pathway in heart failure: a review and guide on the use of sacubitril/valsartan. Heart. 2016;102(17):1342-7.

81. Di Angelantonio E, Chowdhury R, Sarwar N, Ray KK, Gobin R, Saleheen D, Thompson A, Gudnason V, Sattar N, Danesh J. B-type natriuretic peptides and cardiovascular risk: systematic review and meta-analysis of 40 prospective studies. Circulation. 2009;120(22):2177-87.

82. Barbato E, Bartunek J, Marchitti S, Mangiacapra F, Stanzione R, Delrue L, Cotugno M, Di Castro S, De Bruyne B, Wijns W, Volpe M, Rubattu S. NT-proANP circulating level is a prognostic marker in stable ischemic heart disease. Int $\mathrm{J}$ Cardiol. 2012;155(2):311-2.

83. Sabatine MS, Morrow DA, de Lemos JA, Omland T, Sloan S, Jarolim P, Solomon SD, Pfeffer MA, Braunwald E. Evaluation of multiple biomarkers of cardiovascular stress for risk prediction and guiding medical therapy in patients with stable coronary disease. Circulation. 2012;125(2):233-40.

84. Niccoli G, Conte M, Marchitti S, Montone RA, Fracassi F, Grippo R, Roberto M, Burzotta F, Trani C, Leone AM, Bianchi F, Di Castro S, Volpe M, Crea F, Rubattu S. NT-proANP and NT-proBNP circulating levels as predictors of cardiovascular outcome following coronary stent implantation. Cardiovasc Revasc Med. 2016;17(3):162-8.

85. Barbato E, Rubattu S, Bartunek J, Berni A, Sarno G, Vanderheyden M, Delrue L, Zardi D, Pace B, De Bruyne B, Wijns W, Volpe M. Human coronary atherosclerosis modulates cardiac natriuretic peptide release. Atherosclerosis. 2009;206(1):258-64. 
86. McKie PM, Cataliotti A, Sangaralingham SJ, Ichiki T, Cannone V, Bailey KR, Redfield MM, Rodeheffer RJ, Burnett JC Jr. Predictive utility of atrial, $\mathrm{N}$-terminal pro-atrial, and $\mathrm{N}$-terminal pro-B-type natriuretic peptides for mortality and cardiovascular events in the general community: a 9-year follow-up study. Mayo Clin Proc. 2011;86(12):1154-60.

87. Welsh P, Doolin O, Willeit P, Packard C, Macfarlane P, Cobbe S, Gudnason V, Di Angelantonio E, Ford I, Sattar N. N-terminal pro-B-type natriuretic peptide and the prediction of primary cardiovascular events: results from 15-year follow-up of WOSCOPS. Eur Heart J. 2013;34(6):443-50.

88. Barbato A, Sciarretta S, Marchitti S, Iacone R, Di Castro S, Stanzione R, Cotugno M, Ippolito R, Palmieri L, Calvieri C, Battistoni A, Volpe M, Strazzullo P, Rubattu S, Olivetti Heart Study Research Group. Aminoterminal natriuretic peptides and cardiovascular risk in an Italian male adult cohort. Int J Cardiol. 2011;152(2):245-6.

89. Kara K, Lehmann N, Neumann T, Kälsch H, Möhlenkamp S, Dykun I, Broecker-Preuss M, Pundt N, Moebus S, Jöckel KH, Erbel R, Mahabadi AA. NT-proBNP is superior to BNP for predicting first cardiovascular events in the general population: the Heinz Nixdorf Recall Study. Int J Cardiol. 2015;183:155-61.

90. Natriuretic Peptides Studies Collaboration, Willeit P, Kaptoge S, Welsh P, Butterworth AS, Chowdhury R, Spackman SA, Pennells L, Gao P, Burgess S, Freitag DF, Sweeting M, Wood AM, Cook NR, Judd S, Trompet S, Nambi V, Olsen MH, Everett BM, Kee F, Ärnlöv J, Salomaa V, Levy D, Kauhanen J, Laukkanen JA, Kavousi M, Ninomiya T, Casas JP, Daniels LB, Lind L, Kistorp CN, Rosenberg J, Mueller T, Rubattu S, Panagiotakos DB, Franco OH, de Lemos JA, Luchner A, Kizer JR, Kiechl S, Salonen JT, Goya Wannamethee S, de Boer RA, Nordestgaard BG, Andersson J, Jørgensen T, Melander O, Ballantyne ChM, DeFilippi Ch, Ridker PM, Cushman M, Rosamond WD, Thompson SG, Gudnason V, Sattar N, Danesh J, Di Angelantonio E, Natriuretic Peptides Studies Collaboration. Natriuretic peptides and integrated risk assessment for cardiovascular disease: an individual-participant-data meta-analysis. Lancet Diabetes Endocrinol. 2016;4(10):840-9.

91. Van der Leeuw J, Beulens JW, van Dieren S, Schalkwijk CG, Glatz JF, Hofker MH, Verschuren WM, Boer JM, van der Graaf Y, Visseren FL, Peelen LM, van der Schouw YT. Novel biomarkers to improve the prediction of cardiovascular event risk in type 2 diabetes mellitus. J Am Heart Assoc. 2016;5(6):e003048.

92. Rost NS, Biffi A, Cloonan L, Chorba J, Kelly P, Greer D, Ellinor $\mathrm{P}$, Furie KL. Brain natriuretic peptide predicts functional outcome in ischemic stroke. Stroke. 2012;43(2):441-5.

93. Omland T, Sabatine MS, Jablonski KA, Rice MM, Hsia J, Wergeland R, Landaas S, Rouleau JL, Domanski MJ, Hall C, Pfeffer MA, Braunwald E, PEACE Investigators. Prognostic value of B-type natriuretic peptides in patients with stable coronary artery disease: the PEACE trial. J Am Coll Cardiol. 2007;50(3):205-14.

94. Folsom AR, Nambi V, Bell EJ, Oluleye OW, Gottesman RF, Lutsey PL, Huxley RR, Ballantyne CM. Troponin T, N-terminal pro-B-type natriuretic peptide, and incidence of stroke: the atherosclerosis risk in communities study. Stroke. 2013;44(4):961-7.

95. Stanzione R, Sciarretta S, Marchitti S, Bianchi F, Di Castro S, Scarpino S, Cotugno M, Frati G, Volpe M, Rubattu S. C2238/ aANP modulates apolipoprotein E through Egr-1/miR199a in vascular smooth muscle cells in vitro. Cell Death Dis. 2015;6:e2033.

96. Rubattu S, Marchitti S, Bianchi F, Di Castro S, Stanzione R, Cotugno M, Bozzao C, Sciarretta S, Volpe M. The C2238/ $\alpha$ ANP variant is a negative modulator of both viability and function of coronary artery smooth muscle cells. PLoS One. 2014;9(11):e113108.

97. Kook H, Itoh H, Choi BS, Sawada N, Doi K, Hwang TJ, Kim KK, Arai H, Baik YH, Nakao K. Physiological concentration of atrial natriuretic peptide induces endothelial regeneration in vitro. Am J Physiol Heart Circ Physiol. 2003;284(4):H1388-97.

98. Rubattu S, Sciarretta S, Valenti V, Stanzione R, Volpe M. Natriuretic peptides: an update on bioactivity, potential therapeutic use, and implication in cardiovascular diseases. Am J Hypertens. 2008;21(7):733-41.

99. Larifla L, Déprez I, Pham I, Rideau D, Louzier V, Adam M, Eloit M, Foucan L, Adnot S, Teiger E. Inhibition of vascular smooth muscle cell proliferation and migration in vitro and neointimal hyperplasia in vivo by adenoviral-mediated atrial natriuretic peptide delivery. J Gene Med. 2012;14(7):459-67.

100. Rubattu S, Volpe M. High natriuretic peptide levels and low DBP: companion markers of cardiovascular risk? J Hypertens. 2014;32(11):2142-3.

101. Wang TJ, Larson MG, Levy D, Benjamin EJ, Leip EP, Omland T, Wolf PA, Vasan RS. Plasma natriuretic peptide levels and the risk of cardiovascular events and death. $\mathrm{N}$ Engl J Med. 2004;350(7):655-63.

102. Geng Z, Huang L, Song M, Song Y. N-terminal pro-brain natriuretic peptide and cardiovascular or all-cause mortality in the general population: a meta-analysis. Sci Rep. 2017;7:41504.

103. Paget V, Legedz L, Gaudebout N, Girerd N, Bricca G, Milon H, Vincent M, Lantelme P. N-terminal pro-brain natriuretic peptide: a powerful predictor of mortality in hypertension. Hypertension. 2011;57(4):702-9.

104. Pavasini R, Tavazzi G, Biscaglia S, Guerra F, Pecoraro A, Zaraket F, Gallo F, Spitaleri G, Contoli M, Ferrari R, Campo G. Amino terminal pro brain natriuretic peptide predicts all-cause mortality in patients with chronic obstructive pulmonary disease: systematic review and meta-analysis. Chronic Respiratory Disease 2017;14(2):1-10.

105. Van den Borst B, Gosker HR, Wesseling G, de Jager W, Hellwig VA, Snepvangers FJ, Schols AM. Low-grade adipose tissue inflammation in patients with mild-to-moderate chronic obstructive pulmonary disease. Am J Clin Nutr. 2011;94(6):1504-12.

106. Cebron Lipovec N, Beijers RJ, van den Borst B, Doehner W, Lainscak M, Schols AM. The prevalence of metabolic syndrome in chronic obstructive pulmonary disease: a systematic review. COPD. 2016;13(3):399-406.

107. Meems LMG, Burnett JC Jr. Innovative therapeutics. Designer natriuretic peptides. J Am Coll Cardiol Basic Trans Sci. 2016;1:557-67.

108. Costello-Boerrigter LC. Cardiac natriuretic peptides: contributors to cardiac cachexia or possible anti-obesity agents or both? Diabetes. 2012;61(10):2403-4.

109. McMurray JJ, Packer M, Desai AS, Gong J, Lefkowitz MP, Rizkala AR, Rouleau JL, Shi VC, Solomon SD, Swedberg K, Zile MR, PARADIGM-HF Investigators and Committees. Angiotensin-neprilysin inhibition versus enalapril in heart failure. N Engl J Med. 2014;371(11):993-1004.

110. Williams B, Cockcroft JR, Kario K, Zappe DH, Brunel PC, Wang Q, Guo W. Effects of sacubitril/valsartan versus olmesartan on central hemodynamics in the elderly with systolic hypertension: the PARAMETER study. Hypertension. 2017;69(3):411-20. 